\title{
OSMIJEH NA POSLANIKOVOM, S.A.V.S., LICU
}

\section{Sažetak}

U vremenu preokupacije ljudi dunjaluckkim potrebama, njihov osmijeh na licu je zamijenila briga, tuga i potistenost. To stanje je preraslo u pesimizam i rezultiralo je prekidom odnosa medu ljudima ili svodenjem njihove komunikacije na ono poslovno, minimalno.

Lice vjernika koji svojim životom nastoji oponašati najvećeg autoriteta, Mubammeda, s.a.v.s., je ozareno, nasmijano. Ovaj rad ima za cilj da ljudima pokaře kako da pokušaju povratiti nadu $i$ optimizam u njihovim promišljanjima, kako bi njihova lica ponovo bila nasmijana i ozarena.

Osmijehom se približavamo milosti našeg Stvoritelja i osmijeh je taj koji čini bogatim $i$ one koji ga daju $i$ one koji ga primaju.

Ključne riječi: hadis, sunnet, poslanikov osmijeh

\section{Uvod}

Svakodnevne obaveze su čovjeku nametnule takav tempo života koji je teško izdržati. Pored toga što se ljudi nemaju vremena obilaziti i posjećivati, došlo je vrijeme da se nemaju vremena skoro ni poselamiti, upitati za zdravlje. Takva situacija je ljude učinila zabrinutim, potištenim, često i namrštenim, pa nemaju vremena ni da se nasmiješe jedan drugom. Odlika i karakteristika vjernika je da bude nasmijan. Ponekad čovjek, i pored želje da učini dobro djelo, to nije u mogućnosti zbog toga što nema viška imetka kojeg bi podijelio. Poslanik, s.a.v.s., nas upućuje na djelo koje nas ne košta ni para ni vremena, niti bilo kakvog zahmeta, a za to ćemo biti kod Allaha, dž. š., nagrađeni. Poslanik, s.a.v.s., kaže:

$$
\text { (تبسمك في وجه أخيك صدقة) }
$$

Tvoj osmijeh upućen tvom bratu je sadaka.

(أنكم لن تسعوا الناس بأموالكم فليسعهم منكم بسط الوجه وحسن الخلق) رواه مسلم

\footnotetext{
${ }^{1}$ Islamski pedagoški fakultet u Bihaću
} 
„Vi ljude nećete moći radovoljiti niti podmiriti svojim novcem ali cete ib moći podmiriti svojim osmijehom i lijepim ponašanjem. "2

To djelo nije veliko, niti ga je teško uraditi, pa Poslanik, s.a.v.s., dalje upućuje i kaže:

$$
\text { والبيهي في شعب الإيمان (لا تحقرن من المعروف شيئاً ولو أن تلقى أخاك بوجه طليق) }
$$

„Nemoj od dobrih dijela ništa potcienjivati, pa makar da svoga brata sretnes nasmijana lica." 3

Kada skupe tablete sedativa ne mogu pomoći opuštanju, postoji jedan prastari, neobičan, besplatan lijek: osmijeh i smijeh. Ko njega koristi, ne samo da će sačuvati zdravlje, već i zdravlje svojih najbližih: članova porodice, rođaka, prijatelja i saradnika.

Psiholozi ističu da je smijeh čovjekova potreba, da je izgubljen dan u kojem se nismo nasmijali, u kojem svoj osmijeh nismo podarili nekom.

U smijehu je više čovječnosti nego u strogoj ozbiljnosti. Smijati se znači osloboditi se napetosti, ukočenosti, pesimizma, crnih misli. Osmijeh je snaga koja ljude približava, sjedinjuje, razgaljuje, kako u krugu porodice, tako i u društvu... Zato, bez obzira na svakodnevne probleme, ne idite namrgođeni, ljutiti, kao da su vam svi krivi, kao da je sve propalo.

Smijeh i osmijeh treba razumjeti kao svakodnevnu potrebu, kao nasušni hljeb, kao preventivu za očuvanje zdravlja.

Osmijeh čini bogatim one koji ga daruju i one koji ga primaju.

Malo je u životu naučio, ko nije naučio da se raduje i smije.

Pokušajte da budete ljubazni, da se nasmiješite, zbog toga nećete doživjeti neprijatnosti... Igrajte se više sa vašom djecom, šalite se s prijateljima, saradnicima, to će svima biti drago, opustit će, razveseliti i nasmijati, odagnati eventualne crne misli i povratiti radost života. (Ismet Dedić)

\footnotetext{
${ }^{2}$ Hadis je zabilježio Muslim.

${ }^{3}$ Hadis je zabilježio Hakim u Mustedreku i Bejheki u Šuabul-imanu.
} 


\section{Osmijeh na Poslanikovom, s.a.v.s., licu}

Hvala Allahu, dž. š., koji nam je poslao Muhammeda, s.a.v.s., da nam bude uzor $u$ našem životu i neka je salavat i selam na njega, njegovu časnu porodicu, njegove ashabe i sve one koji ga budu slijedili do Sudnjeg dana.

U historiji čovječanstva nema osobe o kojoj je pisano sa više ljubavi i pažnje od Muhammeda, s.a.v.s. Čak su i učenjaci koji su pisali o ličnosti Allahovog Poslanika, s.a.v.s., izdvojili zasebnu vrstu literature koja se bavila ovom tematikom, a to su kutušsemail, tj. knjige koje govore o detaljima Poslanikovog, s. a. v .s., izgleda i visini njegovih moralnih osobina.

Ashabi su ga mnogo poštovali. Pojedinci ga, iz stida i poštovanja prema njemu, nisu mogli ni gledati u lice, a istovremeno su žudili za njegovom blizinom. Pojedinci bi iznalazili razloge i povode da se s njim, s.a.v.s., sretnu. Opet, oni koji bi s njim razgovarali, imali su osjećaj da su mu oni najdraži na svijetu i da su najbolji ljudi, zbog njegove ljubazne komunikacije i posvećenosti sagovorniku.

Evo kako generacija onih koji su bili počašćeni druženjem sa njim objašnjavaju te Poslanikove, s.a.v.s., vrline:

عن عمرو بن العاص قال: (كان رسول الله صلى الله عليه وسلم يقبل بوجها وحديثه على أشر

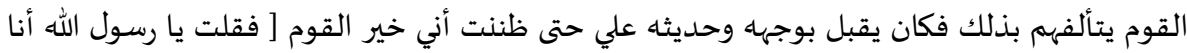

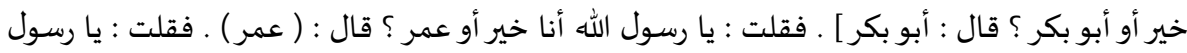

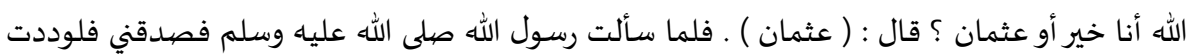
أني لم أكن سألتـه)

Amr ibn El-A's, r.a., kaže: „Allahov Poslanik, s.a.v.s., kada bi rasgovarao $i$ sa najgorim ljudima lijepo bi ih gledao u lice i ljubazno bi im se obraćao, pokušavajuci time da pridobije njïhova srca. Jednom prilikom kada je sa mnom razgovarao prijazno mi se okrenuo svojim licem i ljubazno mi se obratio tako da sam pomislio da sam ja najbolji covjek, pa sam ga upitao: - Allahov Poslaniče, jesam li ja bolji ili Ebu Bekr? On rě̌e: - Ebu Bekr. Ja opet upitah: - Allahov Poslaniče, jesam li ja bolji ili Omer? On rě́e: - Omer. Ja ponovo upitab: - Allahov Poslaniče, jesam li 
ja bolji ili Osman? On reče: - Osman. Nakon što sam Poslanika, s.a.v.s., to pitao $i$ on mi je iskreno odgovorio, poželio sam da ga nisam o tome ni pitao." 4

عن جرير بن عبد الله رضي الله عنه قال :(ما حجبني رسول الله صلى الله عليه وسلم منذ

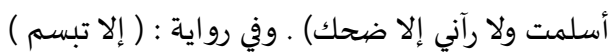

Džerir ibn Abdullah, r.a., kaže: „Otkako sam primio islam nikada mi Allahov Poslanik, s.a.v.s., nije zabranio da uđem kod njega niti me je kada pogledao a da mi se nije nasmijao (u drugoj predaji stoji: „nasmiješio")."

\section{Poslanik umjerenosti i srednjeg puta}

Allahov Poslanik, s.a.v.s., je tokom svog života prolazio kroz razne situacije, radosti, veselja, žalosti, nelagode i tuge, i sa svim tim situacijama i okolnostima se nosio dostojanstveno i umjereno, upućujući i svoje sljedbenike kako treba da se odnose u takvim situacijama. S obzirom da smo mi pripadnici ummeta srednjeg, umjerenog puta, na što ukazuje kur'anski ajet:

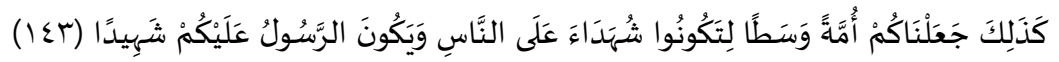

„I Mi smo tako vas učnili zajednicom središnjom da biste bili svjedoci protiv svijeta ostalog, $i$ da Poslanik bude protiv vas svjedok "6 tako nas je i Poslanik, s.a.v.s., svojom praksom podučavao, držeći se u svim spomenutim i sličnim situacijama sredine i umjerenosti. Ako se veselio, nije prelazio granicu u tom veselju, a ako je za nečim žalio, ni tada nije prelazio mjeru. Upravo zbog toga se spominje da je i njegovo smijanje i veselje bilo umjereno i u granicama, onoga koji je svjestan da ga Allah, dž. š., uvijek vidi. Na to ukazuju predaje koje govore o načinu na koji se Poslanik, s.a.v.s., smijao, bolje rečeno o tome da je blagi osmijeh bio sastavni dio opisa njegovog mubarek lica.

عن عبد الله بن الحارث بن جزء رضي الله عنه أنه قال : ( ما رأيت أحدا أكثر تبسما من رسول

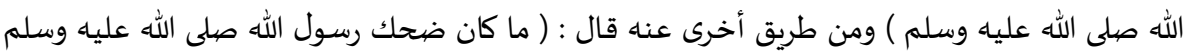

\footnotetext{
${ }^{4}$ Hadis je sahih a bilježe ga Buhari, Musilim (2385) i Tirmizi u Ešššmailul-muhammedijje, broj: 327.

${ }^{5}$ Hadis je sahih a bilježe ga Buhari, Muslim (2475) i Tirmizi u Ešššmailul-muhammedijje, broj: 231 .

${ }^{6}$ Sura El-Bekare, 143.
} 
Abdullah ibn El-Haris ibn Džez', r.a., je rekao: „Nisam nikoga vidio da se više smiješio od Allahovog Poslanika, s.a.v.s. U drugoj predaji ovog hadisa se kaže: Smijeh Allahovog Poslanika, s.a.v.s., nije bio ništa nego blagi osmijeh na njegovom licu." stoji:

Ovo potvrđuje i slična predaja od Džabira ibn Semure, r.a., u kojoj

عن جابر بن سمرة رضي الله عنه قال : ( ...كان رسول الله صلى الله عليه وسلم لا يضحك إلا

„Allahov Poslanik, s.a.v.s., se nije smijao osim blagim osmijehom."8

Pored toga što je Allahov Poslanik, s.a.v.s., svoj ummet podučavao umjerenom načinu smijanja svojim ponašanjem, to je činio i riječima, podstičući ih na umjerenost u svemu, pa čak i u smijanju.

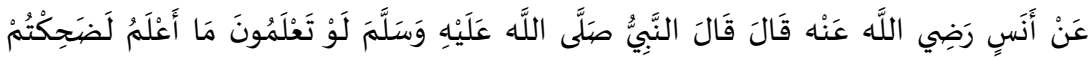

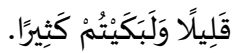

Enes ibn Malik, r.a., pripovijeda od Allahovog Poslanika, s.a.v.s., da je rekao: „Kada biste znali ono sto ja znam, malo biste se smijali, a mnogo biste plakali. "9

Kao povod izreke ovog hadisa, u predaji koju bilježi Taberani navodi se, slijedeći događaj:

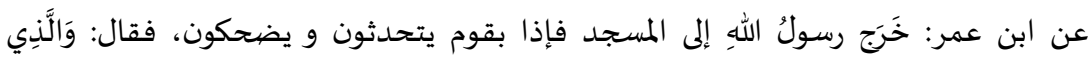

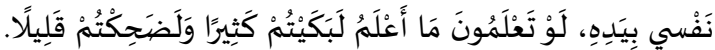

Abdullah ibn Omer, r.a., kaže: Jednom prilikom je Allahov Poslanik, s.a.v.s., ǔsao u džamiju $i$ zatekao ljude kako razgovaraju $i$ smiju se pa im je rekao: „Tako mi Onoga u Cijoj ruci je moja duša, kada bi znali ono što ja znam, malo biste se smijali, a mnogo biste plakali. ‘d0

Ovaj hadis ne treba razumjeti da se čovjek ne treba smijati i da mu je to haram/zabranjeno. Međutim, vjernik u svemu treba da ima mjeru i

\footnotetext{
7 Hadis je sahih a bilježi ga Tirmizi u Sunenu (3645) i u Ešššmailul-muhammedijje, broj: 217. i ovo je od hadisa s kojima se on izdvaja od ostalih autora.

${ }^{8}$ Hadis je daif a bilježi ga Tirmizi u Sunenu (3648) i u Ešššmailul-muhammedijje, broj: 193.

${ }^{9}$ Hadis je zabilježio Buharija 11/319 (6486) u Kitabur-rikak i Tirmizi 6/603 (2415) u

Kitabuz-zuhdu od Ebu Hurejre.

${ }_{10}$ Pogledaj Fethul-Bari 11/320 i Tubfetul-abvezi 6/603.
} 
da se drži umjerenosti, pa je takva situacija i sa smijanjem u kojem ne treba da prelazi granicu. Čovjek bi, bar s vremena na vrijeme, trebao da plače zbog svojih grijeha i propusta, zato što Poslanik, s.a.v.s., u ovom hadisu kaže: „Kada bi qnali ono što ja ₹nam", tj. kada biste znali strahotu Allahove, dž. š., kazne za grješnike i poteškoću polaganja računa na Sudnjem danu, "malo bi se smijali, a mnogo bi ste plakali", tj. dugo biste plakali iz straha od Allaha, dž. š., i bojeći se ružnog završetka (su'ulhatime) na ovom svijetu.

Hasan el-Basri kaže: „Ko bude svjestan da mora umrijeti zatim biti

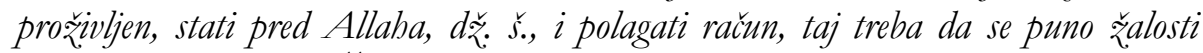
(plače) na dunjaluku." 11

Evo hadisa u kojem Allahov Poslanik, s.a.v.s., hvali i obećava nagradu očima koje budu suzile iz straha od Allahove, dž. š., patnje:

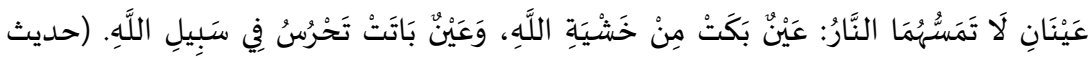

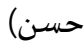

„Dva oka ď̌ehennemska vatra neće dotaći: oko koje plače iz strahopoštovanja

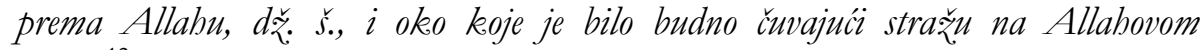
putu. ${ }^{\text {a2 } 2}$

Prethodni hadisi nas podsjećaju i pripremaju za polaganje računa na Sudnjem danu. Iz spomenutog se može zaključiti da je pokuđeno pretjerano i nekontrolisano smijanje, jer je Poslanikov, s.a.v.s., način smijanja bio samo blagi osmijeh na licu, bez dizanja glasa. Ovakvi tekstovi nas podstiču i na razmišljanje o teškoćama Sudnjeg dana i da je potrebno povremeno plakati zbog vlastitih grijeha i izbjegavati pretjerano smijanje. Učenjem Kur'ana, spominjanjem Allaha, dž. š., mi činimo svoja srca smirenim i čistimo ih od ružnih osobina i oholosti.

\section{Šala je dozvoljena}

Prethodne hadise ne treba razumjeti da se u islamu nije dozvoljeno šaliti, niti smijati. Sve je to dozvoljeno i s vremena na vrijeme je potrebno da se čovjek našali, nasmije, igra sa članovima svoje familije, posebno sa djecom koja to očekuju od svoga oca. Evo nekoliko hadisa koji ukazuju na to:

11 Pogledaj Fethul-Bari 11/320.

12 Hadis je hasen, a zabilježio ga je Tirmizi. 
Enes, r.a., prenosi i da bi se Vjerovjesnik, s.a.v.s., nasmiješio kada bi prolazio pored djece i nazivao im selam! $\mathrm{Na}$ taj način privlačimo pažnju djece i prodobijamo njihove simpatije.

Ebu Hurejre, r.a., prenosi da je Vjerovjesnik, s.a.v.s., poljubio svoga unuka Hasana, sina Alijinog, pa mu je El'-Akre ibn Habis kazao: 'Ja imam desetero djece i nijedno od njih nikeada nisam poljubio!" Allahov Poslanik, s.a.v.s., mu reče: "Né́e se ukazati milost onome koji nema milosti."

Poslanik, s.a.v.s., se šalio sa svojim ashabima, ali je uvijek bio iskren. Nije sebi dozvoljavao da govori neistinu, pa makar to bilo u šali. $\mathrm{U}$ hadisima je Poslanik, s.a.v.s., podsticao na iskrenost u govoru pa makar se radilo i o šali:

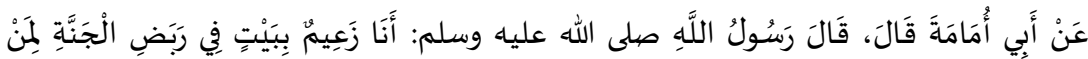

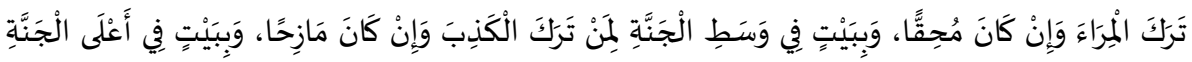
لمِنْ حَسَّنَ خُلُقَهُ.

Prenosi se od Ebu Umameta, r.a., da je Allahov Poslanik, s.a.v.s., rekao:

„Ja garantujem kuíu u podnožju Dřeneta onom ko ostavi raspravu pa makar bio u pravu, garantujem kucu u sredini Dženeta onom ko ostavi lažpa makar ona bila $i$ u šali i garantujem kucu u najvišem dijelu Dřeneta onom ko uljep̌ra svoje ponašanje. " 14

Navest ćemo nekoliko situacija u kojima se Poslanik, s.a.v.s., našalio:

عن أبي هريرة رضي الله تعالى عنه قال : قالوا : يا رسول الله إنك تداعبنا ـ قال : ( نعم غير أني

لا أقول إلاحقا)

Ebu Hurejre, r.a., prenosi da je rečeno: „Allahov Poslaniče, ti se wistinu s nama šališ? "On rěce: „Da, ali ja ne govorim ništa nego samo istinu. "'5

Evo i drugog primjera iz svakodnevnog Poslanikovog, s.a.v.s., života:

\footnotetext{
${ }^{13}$ Hadis je zabilježio Buharija.

${ }^{14}$ Hadis su zabilježili Ebu Davud 13/156 (4776), Tirmizi 6/128 (2061) i drugi.

15 Hadis je sahih a bilježi ga Tirmizi u Sunenu (1991) i u Ešš̌̀emailul-muhammedijje, broj: 227. i ovo je od hadisa s kojima se on izdvaja od ostalih autora.
} 
عن أنس بن مالك : أن رجلا استحمل رسول الله صلى الله عليه وسلم . فقال : (إني حاملك

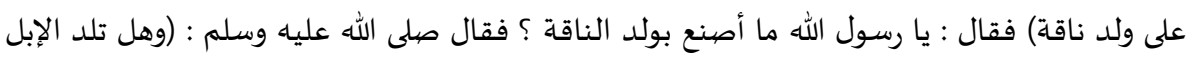

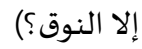

Enes ibn Malik, r.a., priča: „Neki covjek je tră̌io od Allahovog Poslanika, s.a.v.s., da mu dadne jahalicu (kako bi išao u borbu), pa mu Poslanik, s.a.v.s., rě̌e: „Ja ín ti dati mladunče deve." Covjek tada rě̌e: „Pa šta ću od mladunčta deve?" Poslanike mu rě̌e: „Pa zar sve (pa i odrasle) deve nisu mladunčad (starijih) deva!? "ה6

I još jedan vrlo interesantan primjer Poslanikove, s.a.v.s., šale sa ashabima:

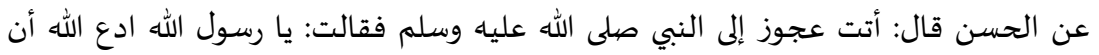

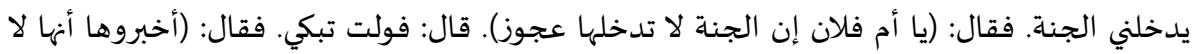

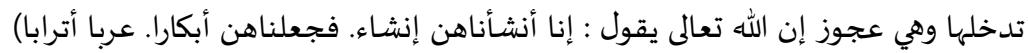

Hasan je rekao: „Neka starica je došla Vjerovjesniku, s.a.v.s., i rekla mu: „O Allahov Poslaniče, moli Allaha da me wvede u Dřennet!" Poslanik, s.a.v.s., joj reče: „O majko tog $i$ tog, zaista starci né́e uci u Dřennet. "Ona se tada okrenula $i$ počela plakati, pa Poslanik, s.a.v.s., rě̌e prisutnima: „Obavijestite je da ona né́e níi u Dřennet kao starica, jer Allah, ďّ. š, u Kur'anu kaže: „A zibilja ćemo stvaranjem novim hurije stvoriti, $i$ djevicama ih učiniti, milim muževima njïhovim, $i$ godina istih. "(sura El-Vaki'a, 35-37) ${ }^{17}$

Razni su povodi i situacije bile razlogom da se Allahov Poslanik, s.a.v.s., nasmije ili bar nasmiješi. Evo nekih od tih situacija:

\section{Smijeh zbog Allahove, dž.š., milosti}

عن أبي ذر رضي الله عنه قال : قال رسول الله صلى الله عليه وسلم :( إني لأعلم أول رجل

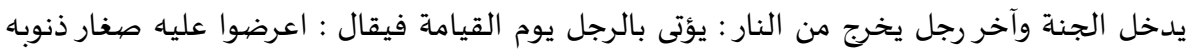

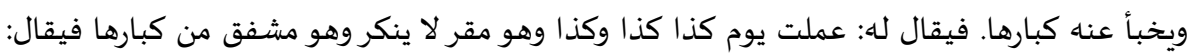

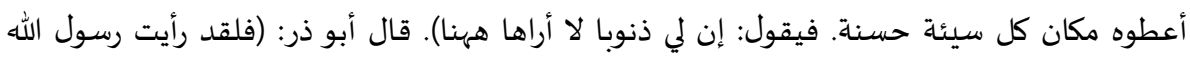
صلى الله عليه وسلم ضحك حتى بدت نواجذهان

\footnotetext{
${ }^{16}$ Hadis je sahih a bilježe ga Ebu Davud (4998) Tirmizi u Ešš Šemailul-muhammedijje, broj: 229.

${ }^{17}$ Hadis je hasen a bilježi ga Tirmizi u Eš-Šemailul-muhammedïje, broj: 229.
} 
Ebu Zerr, r.a., prenosi da je Allahov Poslanik, s.a.v.s., rekao: „Ja

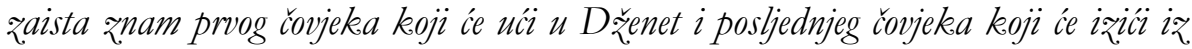
Dřehenema: Taj covjek će biti doveden na Sudnjem danu pa će se reći: „Poką̌ite mu njegove male grijehe a prikrijte njegove velike grijehe!"Zatim će mu se reći: „Tog i tog dana si uradio to $i$ to. "On će to sve priznati $i$ neće nista od toga poricati, bojeći se svojih velikih grijeha. Zatim ce se reći: „Zamijenite sve njegove grijehe dobrim djelima." Tada će taj covjek reći: „Ja sam počinio grijehe koje ne vidim ovdje." Ebu Zerr, r.a., kað̌e: „Pa sam vidio Allahovog Poslanika, s.a.v.s., da se nasmijao toliko da su mu se vidjeli kutni zubi. "A8

عن عبد الله بن مسعود رضي الله عنه قال : قال رسول الله صلى الله عليه وسلم : ( إني

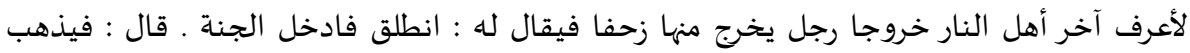

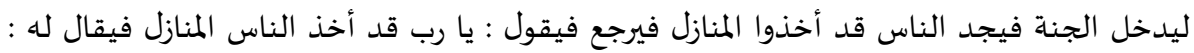

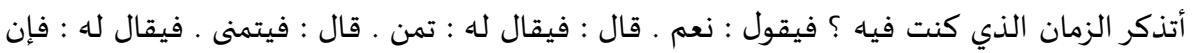

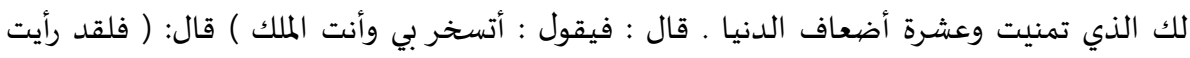

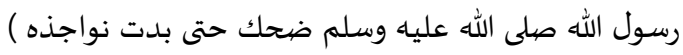

Abdullah ibn Mes'ud, r.a., prenosi da je Allahov Poslanik, s.a.v.s., rekao: Ja zaista znam coovjeka koji će posljednji izicici iz. Vatre i koji će izicí purećí. Zatim će mu se reći: „Idi i uđi u Dřenet!" On će otići da ude pa će naći ljude kako su već zauzeli svoja mjesta. Vatit će se i reći: „Gospodaru, ljudi su već zauzeli svoja mjesta." Tada će mu se reći: „Sjećaš li se onoga vremena u kojem si bio?" On će reći: „Sjećam." Tada će mu se reći: „Poželi șto hoćeș!" On će poželjeti, pa će mu se reći: „Bice ti dato to sto si poželio i još deset puta koliko vrijedi sve sto je na dunjaluku." Tada će covjek začudeno reći: „Pa zar se Ti sa mnom ismijavas,, a Ti si Gospodar?!" Ibn Mes'ud, r.a., reče: „Pa sam vidio Allahovog Poslanika, s.a.v.s., da se nasmijao toliko da su mu se vidjeli kutni zubi."19

\section{Osmijeh zbog Allahove, dž. š., blagodati}

Ponekada bi se Poslanik, s.a.v.s., prisjetio neke od Allahovih, dž. š., blagodati, pa bi se osmjehnuo.

علي بن ربيعة قال: شهدت عليا رضي الله عنه أتي بدابة ليركبها فلما وضع رجله في الركاب قال

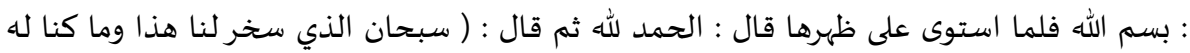

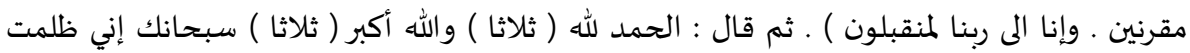

18 Hadis je sahih a bilježe ga Buhari, Muslim(190) i Tirmizi u Eššsemailul-muhammedijje, broj: 219.

${ }^{19}$ Hadis je sahih a bilježe ga Buhari, Muslim(186), Tirmizi i Ibn Madže (4339). 
نفسي فاغفر لي فإنه لا يغفر الذنوب إلا أنت ) . ثم ضحك ـ فقلت له : من أي شيء ضحكت يا أمير

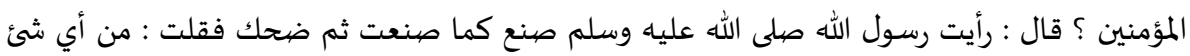

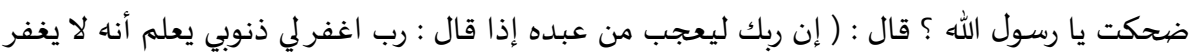

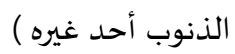

Alija ibn Rebi'a je rekao: „Bio sam prisutan kada je Aliji, r.a., dovedena jahalica da je urjaše. Kada je stavio svoju nogu u uz̧engiju rekao je: „Bismillah. "Zatim je u§jahao pa je rekao: „El-hamdu lillah." Onda je proučio: „Subhanelleri sehbare lena haza ve ma kunna lebu mukrinin ve inna ila rabbina le munkalibun/Slavljen $i$ Uzvišen neka je Onaj Koji nam je ovo potřinio, mi to sami ne bismo mogli postici, i mi ćemo se sigurno Gospodaru svome vratiti." (sura EzZuhruf, 13.) Zatim je tri puta irgovorio: „El-hamdu lillab“, tri puta: „vallahu ekber", a zatim: "Subbaneke inni zalemtu nefsi, fagfir li fe innebu la jagfiruzzunube illa ente/Hvala Allabu, Allah je najveći. Slava Tebi (moj Gospodaru). Ja sam prema sebi nasilje učinio, pa mi oprosti, jer grijehe ne oprašta niko osim Tebe! "Nakon toga se nasmijao, pa sam ga upitao: „Zašto si se nasmijao o vladaru pravovjernib? "On reče: „Vidio sam Allahovog Poslanika, s.a.v.s., da je uradio isto što sam $i$ ja uradio $i$ onda se nasmijao. " Ja sam ga upitao: „Zašto si se nasmijao o Allahov Poslaniče? "On reče: „Zaista se tvoj Gospodar divi Svome robu kada kaře:e: „Rabbigfir li zunubi/Gospodaru oprosti mi grijehe", a svjestan je da grijehe ne oprasta niko osim Njega."120

عن أبي أمامة أن رسول الله قال يوما لأصحابه هل أصبح منكم اليوم صائما فسكتوا فقال

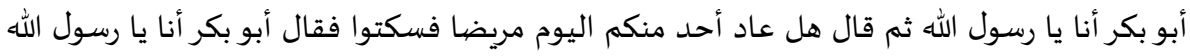

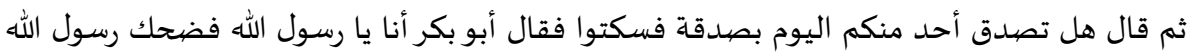

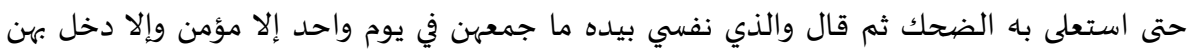
الجنة

Ebu Umame, r.a., priča da je Allahov Poslanik, s.a.v.s., jednog dana upitao svoje ashabe: „Ima li neko od vas da je osvanuo kao postaú?" Svi su šutjeli, pa je Ebu Bekr, r.a., rekao: „Imam ja, Allahov Poslaniče." Poslanik, s.a.v.s., ponovo upita: „Ima li neko među vama da je obišao bolesnika?" Svi prisutni su štjeli, pa je Ebu Bekr, r.a., opet rekao: "Jesam ja, Allahov Poslaniče." Poslanik, s.a.v.s., ponovo upita: „Ima li neko od vas da je podijelio sadaku?" Svi su šutjeli, pa je Ebu Bekr, r.a., rekao: „Jesam ja, Allahov Poslaniče. "Poslanik, s.a.v.s., se tada glasno

${ }^{20}$ Hadis je sahih a bilježe ga Ebu Davud (2602), Tirmizi (3443), Nesai i Ahmed. 
nasmijao, a zatim reče: „Tako mi Onoga u čijoj ruci je moja duša, koji god vjernike sve ovo spomenuti uradi u jednom danu uci će zbog toga u Dřennet." 21

\section{Poslanikov, s.a.v.s., osmijeh zbog šale njegovih ashaba, r.a.}

Ponekad je Poslanik, s.a.v.s., sjedio sa svojim ashabima, pričao sa njima o njihovim životnim situacijama, slušao o njihovim dogodovštinama u vremenu prije islama.

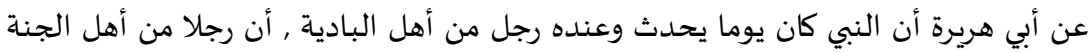

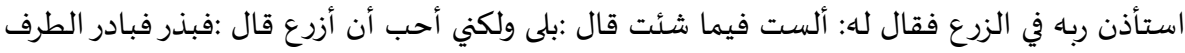

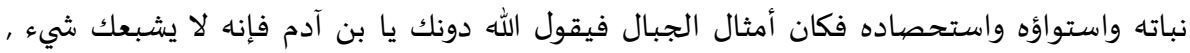

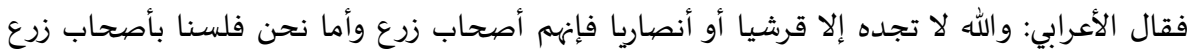
فضحك النبي.

„Ebu Hurejre, r.a., prenosi da je Vjerovjesnik, s.a.v.s., jednoga dana, dok je medu njima bio neki beduin (pastir izpustinje), pričao o tome kako će neki covjek u Dřennetu trą̌iti odobrenje od svoga Gospodara da sije. Allah, d※̌. š, ć mu reći: „Pa zar nemaš sve što želišs?" Covjek će reći: „Imam, ali ja volim sijati. “ Covjek je posijao sjeme pa je nikelo i poraslo poput brda. Tada mu Allah, ď̌. s., reče: „Eto ti covječe, ali te nista ne može zasititi. "Tada taj beduin reče: „Tako mi Allaha, to će vjerovatno biti neki Kurejsija, ili Ensarija (stanovnik Medine) jer oni se bave zemljoradnjom, a mi beduini nismo poljoprivrednici. "Tada se Vjerovjesnik, s.a.v.s., nasmijao." 22

\section{Omerova, r.a., strogost}

Omer, r.a., je bio poznat po svojoj strogosti i principijelnosti po pitanju vjerskih propisa. Bio je vrlo pronicljiv, što potvrđuju slijedeći tekstovi. Alija, r.a., kaže: „Govorili smo da melek govori preko Omerovog jezika“. Ovu izreku pojašnjava slijedeći hadis u kojem Poslanik, s.a.v.s., kaže:

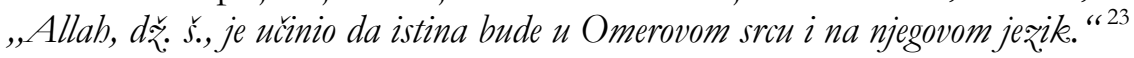

${ }^{21}$ Hadis je zabilježio Taberani u Velikom Mu'džemu, 8/204.

22 Hadis je zabilježio Buhari, 2/826.

${ }^{23}$ Hil-jetul-evlija', 1/42. 
Bilo mu je dozvoljeno da za vrijeme Poslanikovog života sudi. U jednoj predaji stoji da je Poslanik, s.a.v.s., rekao: „Cuvajte se Omerove srdžbe, jer se Allah ljuti abog toga. " 24

Čak su i pojedini kur'anski ajeti objavljeni u skladu sa njegovim mišljenjem. Abdullah ibn Omer, r.a., prenosi da je njegov otac Omer, r.a., rekao: „Moje mišljenje je Allah, ď̌. š., podržao u tri slǘaja: vezano za Mekami-Ibrabim, propis hidžaba i slučaj zarobljenika na Bedr. "Prenosi se da je Omer predložio da se pored Mekami-Ibrahima klanja, pa je objavljen kur'anski ajet u kojem se naređuje da se nakon tavafa klanja dva rekata pored Mekami-Ibrahima. Također je kur'anski tekst podržao Omera po pitanju obaveznosti pokrivanja i njegovo mišljenje o zarobljenicima na Bedru je bilo ispravnije. Poznat je i događaj kada je umro glavni munafik Abdullah ibn Ubejj ibn Selul, Poslanik je pozvan da mu klanja dženazenamaz. „Kada se Poslanik primakao šelecí da mu klanja ď̌enazu, prišao je Omer, r.a., i rekao: „Allahov Poslaniče, pa zar ćeš njemu klanjati ď̌enazu, a on je radio to $i$ to i govorio to $i$ to!?" Poslanik se blago osmjebnuo i rekao: „Pusti me, Omere, meni je dato da izaberem i ja sam izabrao." „Misli na kur'anski ajet o munaficima: 'Molio ti za njihov oprost ili ne molio, pa čak kada bio molio sedamdeset puta za njih, Allah im neće oprostiti." Poslanik tada rě̌e: „Kada bih znao da ce im Allah oprostiti ako budem molio vise od sedamdeset puta, ja bih molio vise od sedamdeset puta." Tada je Poslanik njemu klanjao ď̌enazu, ispratio ga i stajao pored njegovog kabura (moleći za njega). Mnogi su se začudili Omerovoj, r.a., hrabrosti da se protivi Poslaniku, s.a.v.s. Nije prošlo malo vremena nakon toga pa je objavljen ovaj kur'anski ajet: "Nemoj više nikom od njih klanjati, niti stajati pored njegovog

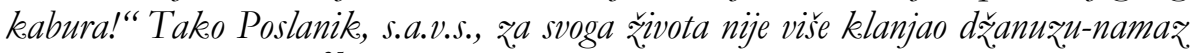
nikom od munafika." "25

Evo nekoliko situacija gdje se Poslanik, s.a.v.s., nasmijao u društvu Omera, r.a., zbog nekog njegovog postupka i tome slično:

عن سعد بن أبي وقاص أنها قال دخل عمر بن الخطاب على رسول الله وعنده نسوة من قريش

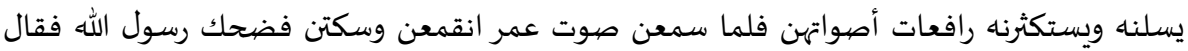

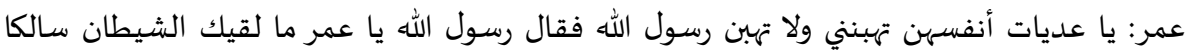

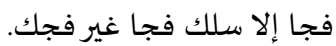

„Sead ibn Ebi Vekekas, r.a., je rekao da je Omer ibn Hattab, r.a., ušao kod Allahovog Poslanika, s.a.v.s., a kod njega su bile neke žene kurejšrvicke koje su

${ }^{24}$ El-E'alam od Ziriklija, 5/45.

${ }^{25}$ Hil-jetul-evlija', 1/42. 
bučno i glasno razgovarale, pa kada su čule Omerov, r.a., glas ustukle su i ǔ̌utale. Na to se Allahov Poslanik, s.a.v.s., nasmijao a Omer, r.a., im je rekao: „O vi koje ste same sebi neprijatelji, bojite se mene a ne bojite se Allahovog Poslanika, s.a.v.s.! Poslanik, s.a.v.s., tada reče: „Omere, kada te šjtan sretne na putu on bjě̌i drugim putem mimo onoga kojim ti ides.

عائشة تقول كانت عندي امرأة تسمعني فدخل رسول الله على تلك الحال ثم دخل عمر التها

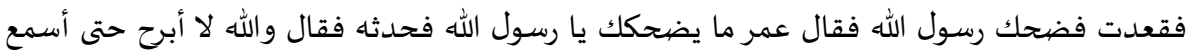

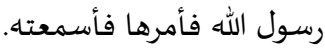

Aiša, r.a., je ispričala: „Kod mene se jednom prilikom nalazila neka そ̌ena koja mi je pjevala nešto. Kada je ušao Allabov Poslanik, s.a.v.s., ona je i dalje isto radila, ali kada je ušao Omer, r.a., ona je sjela. Na to se Allahov Poslanik, s.a.v.s., nasmijao, pa je Omer, r.a., preupitao: "Sta te je nasmijalo, o Allahov Poslaniče?" On mu je to ispričao a onda je rekao: „Tako mi Allaha, nécu se pomaknuti sa ovog mjesta sve dok Poslanike, s.a.v.s., ne čuje od nje to. "On joj je tada naredio da nastavi pjevati i ona je nastavila sve dok, je Poslanik, s.a.v.s., nije poslušao. " ${ }^{27}$

\section{Poslanikov, s.a.v.s., smijeh zbog ljubomore njegovih supruga, r.a.}

U nekoliko situacija Allahov Poslanik, s.a.v.s., bio je prisiljen da rješava sporove među svojim ženama, koji su bili rezultat njihove ljubomore. Evo jedne od tih situacija:

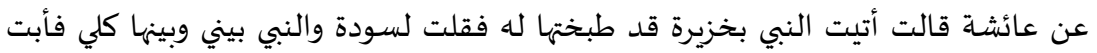

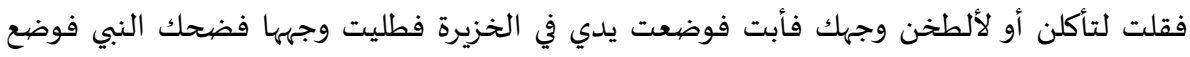

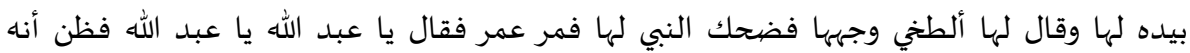

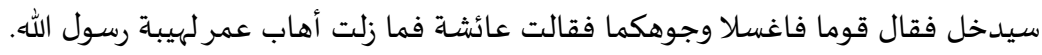

Aiša, r.a., priča: „Donijela sam jednom prilikom hranu Vjerovjesniku, s.a.v.s., koju sam pripremila za njega, a on se tada nalazio kod svoje supruge Sevde. Dok je Vjerovjesnik, s.a.v.s., stajao irmedu nas dvije ja sam joj rekla: „Bujrum, jedi!" Ona nije btjela, a ja sam joj zaprijetila: „Ili ćešs jesti ili ću ti lice umazati tom branom." S obzirom da je ona odbila da jede ja sam rukom zagrabila te hrane $i$ namazala joj lice time. Tada se Vjerovjesnik, s.a.v.s., nasmijao i dodao Sevdi posudu sa hranom, te joj je rekao: „Eh, sada ti nju umą̆i!" Tada se Vjerovjesnik, s.a.v.s., nasmijao i njoj. U tom momentu je prolazio Omer, r.a., pored kuće, te je povikao:

${ }^{26}$ Hadis je zabilježio Ibn Hibban u svom Sahihu, 15/316.

${ }^{27}$ Hadis je zabilježio Ishak ibn Rahujeh u svom Musnedu, 3/664. 
„O Allahov robe, o Allahov robe!" On je pomislio da će Omer, r.a., núi, te je njima dvjema rekao: „Idite i operite svoja lica!“ Aiša, r.a., je tada rekla: „Od tada sam se bojala Omera, r.a., s obæirom da sam vidjela da ga i Poslanik, s.a.v.s., uvažava. "28

\section{Poslanikov, s.a.v.s., smijeh zbog nepromišljene upornosti ashaba, r.a.}

Evo jedne od situacija kada se Poslanik, s.a.v.s., nalazio skupa sa ashabima u vojnom pohodu:

عن عبد الله بن عمر قال: لما حاصر رسول الله الطائف فلم ينل منهم شيئا قال: إنا قافلون إن

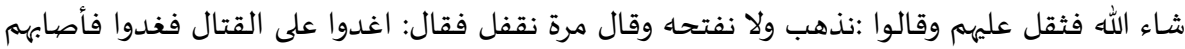
جراح فقال: إنا قافلون غدا إن شاء الله فأعجههم فضحك النبي وقال فالهال سفيان مرة فتبسم.

Abdullah ibn Omer, r.a., pripovijeda: „Kada je Allahov Poslanik, s.a.v.s., opsjedao Taif $i$ nije uspio nista da postigne, rekao je: „Odustajemo i sutra, ako Bog da, kréémo nazad!" To je ashabima teško palo, te su rekli: „Idemo a nismo osvojili Taif." Tada im Poslanik, s.a.v.s., reče: „Onda sutra ujutro kada osvanemo krenut cete opet u napad. "Kada su ashabi dopali rana, Poslanik, s.a.v.s., ponovo reče: „Odustajemo i sutra, ako Bog da, kré́emo nazad!" Sada se to ashabima dopalo (kao da su jedva dočekali naredbu za povlačenje). Na to se Poslanik, s.a.v.s., nasmijao. Sufjan u drugoj predaji kaṣ̌̆: nasmiješio. ${ }^{29}$

Molimo Allaha, dž. š., da nas uputu umjerenosti u svemu i da budemo pravi sljedbenici Muhammeda, s.a.v.s.

\section{Zaključak}

Polazeći od činjenice da je Allahov Poslanik, Muhammed, s.a.v.s., poslan kao milost svim svjetovima, ljudima i džinima, insanima, hajvanima, pa čak i biljkama, svojim životom i praksom trasirao je put kojim njegovi sljedbenici treba da idu. Njegov misionarski rad koji je trajao pune dvadeset i tri godine, kao i njegov četrdesetogodišnjih život prije toga, bio je ispunjen i zračio je blagošću, prijaznošću prema sredini koja ga je okruživala, a koja je ponekada bila i gruba i neprijateljski raspoložena prema njemu. Nije ostavio nikakvo dobro, a da svoje sljedbenike nije na to uputio, niti kakvo zlo, a da ih na to nije

${ }^{28}$ Hadis je zabilježio Ebu Je'ala u svom Musnedu, 7/449.

${ }^{29}$ Hadis je zabilježio Buhari, 4/1572. 
blagovremeno upozorio. Pozivao je u islam svojom riječju, svojim djelima i svojim izgledom koji je plijenio one oko njega.

Jedna od najprimamljivijih metoda koje je Poslanik, s.a.v.s., u svom komuniciranju sa ljudima koristio bila je njegov blagi osmijeh koji je bio sastavni dio i obilježje njegovog lica. Između svega ostalog, to je ono u čemu ga također trebamo oponašati, kako bismo se nadali uspjehu i zaslužili nagradu kod našeg Stvoritelja.

Osmijeh na licima ljudi, to je ono za čim ljudi žude i to je mehlem rana svakom ljudskom biću kojeg je dunjalučka preokupacija danas opteretila. Radujmo se i osmjehnimo se, zato što smo sljedbenici najvećeg uzora u čiji šefa'at/zauzimanje se nakon Allahove, dž.š., milosti nadamo.

\section{Literatura:}

1. Kur'an sprevodom, preveo Besim Korkut, Medina 1412. h. g.

2. El-A'lam od Ez-Ziriklija, Bejrut, VI izdanje, 1984.

3. Fethul-Bari bi šerh sahihil-Buhari, Ahmed ibn Ali ibn Hadžer El-Askalani, Mekteberur-rijad el-hadise

4. El-D染imi'us-sahih, Imam Muslim, Daru ihja'il-kutub, Kairo, 1375. h. g.

5. Es-Sunen, Imam Tirmizi, sa komentarom Tuhfetul-Ahvezi, Darul-fikr

6. Es-Sunen, Imam Ebu Davuda, sa komentarom Avnul-meabud, Darul-fikr, Bejrut, III izdanje.

7. Es-Sunen, Imam Ibn Madže El-Kazvini, El-Mektebe el-ilmije, Bejrut, Liban.

8. Es-Sunen, Imam Nasai, II izdanje, 1412. h. g. - 1992.

9. Ešs-Šremail el-muahmmedijje, od Tirmizije, Darul-matbuatil-hadise, III izdanje, 1409. h. g. -1988.

10. El-Mustedrek, od Hakima, Darul-mearife, Bejrut.

11. El-Musned, od Imama Ahmeda, El-Mekteb el-islami, Bejrut.

12. Šuabul-iman, od Imama Bejhekije.

13. El-Mu'd ̌̌em el-kebir, od Imama Taberanija, Vizaretul-evkaf u Iraku.

14. Hiljetul-evlija, od Ebu Nuajma, Darul-kitab el-arebi, V izdanje, 1407. h. g. - 1987.

15. Es-Sabih od Ibn Hibbana, Muessesetur-risale, II izdanje, 1414. h.g.

16. El-Musned od Ebu Jeala, Darul-kible lissekafe, I izdanje, 1407. h. g.

17. Tefsir Ibn-Kesir, skraćeno izdanje, Muhammed Nesib Er-Rifa'i, prijevod na bosanski grupa prevodilaca, Visoki Saudijski komitet za pomoć BiH, Sarajevo, 2000. (1420. h. g.) 
Fuad Sedic, $\mathrm{PhD}$

\section{THE SMILE ON THE PROPHET'S, PEACE BE UPON HIM, $F A C E$}

\section{ABSTRACT}

Smile on the faces has been replaced by concern, sadness and depression during the time of preoccupation with worldly needs. This condition has evolved into pessimism and disrupted relations between people thus reducing their communication to a basic minimum.

The face of a believer who is trying to follow Muhammad, peace be upon him, is always radiant and smiling. This paper aims to show to people how they can regain bope and optimism in their thinking, and bring back the smile and radiance on their face.

Through smile we bring ourselves closer to the grace of our Creator and the smile makes the rich and those who give and those who receive it.

Keywords: Hadith, Sunnah, Prophet's smile 
الأستاذ الدكتور فؤاد سيديتش

التبسم على وجه رسول الله صلى الله عليه وسلم

الخلاصية

في وقت انشغل الناس بالحاجات الدنيوية فإن الهم والحزن والكآبة حلوا محل

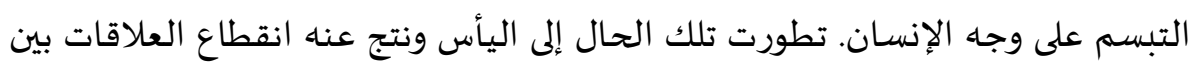
الناس والاقتصار في اتصالاتهم على الضروري لقضاء الأعمال، أو على أقل حد الإند ممكن.

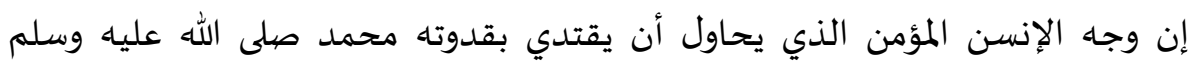
مشمس ومبتسم. إن هدف هذا البحث أن يبين للناس كيف سيعيدون الأمل والتفاءل في

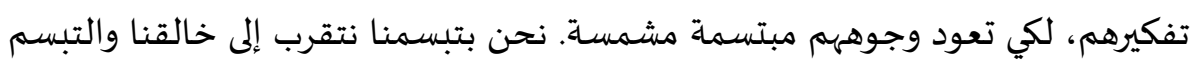
هو الذي يجعل من المعطي والمتلقي أغنياء.

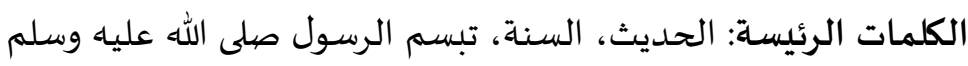

